\title{
Studi Tentang Pengetahuan Masyarakat, Peran Masyarakat Dan Kebijakan Pemerintah Terhadap Keberadaan Taman Nasional Gunung Leuser (TNGL) Studi Kasus Di Desa Ketambe Kabupaten Aceh Tenggara
}

\author{
(Study on Community Knowledge, Community Role and Government Policy on the \\ Existence of Gunung Leuser National Park (TNGL) Case Study in Ketambe Village, \\ Aceh Tenggara District)
}

\author{
Sry Dinda Agustin Sy ${ }^{1}$, Martunis ${ }^{2}$, Ashabul Anhar ${ }^{3 *}$ \\ ${ }^{1}$ Program Studi Kehutanan PSDKU Unsyiah Gayo Lues, UniversitasSyiah Kuala \\ ${ }^{2}$ Program Studi Kehutanan, FakultasPertanian, UniversitasSyiah Kuala \\ ${ }^{3}$ Program Studi Kehutanan, FakultasPertanian, UniversitasSyiahKuala \\ *Corresponding author:ashabul.anhar@unsyiah.ac.id
}

\begin{abstract}
Abstrak. Keberadaan masyarakat di sekitar TNGL merupakan bagian yang tidak terpisahkan dari pengelolaan ekosistem Taman Nasional, sering dihadapkan pada dilema antara kepentingan konservasi keanekaragaman hayati dengan kepentingan dan kebutuhan masyarakat terhadap sumberdaya di TNGL. Penelitian ini bertujuan untuk mengetahui tingkat pengetahuan masyarakat, peran masyarakat dan kebijakan pemerintah terhadap keberadaan TNGL dan melihat faktor-faktor serta tingkat korelasi yang berdampak pada pengetahuan masyarakat, peran masyarakat dan kebijakan pemerintah. Metode yang digunakan dalam penelitian ini yaitu menggunakan Statistical Program From Social Science (SPSS) 22 dan Microsoft Excel 2007. Pengolahan data dilakukan menggunakan rumus Uji Korelasi Spearman Rank untuk menguji hubungan antar variabel. Berdasarkan uji korelasi Rank Spearman pada pengetahuan masyarakat, yakni faktor pekerjaan dan pendidikan berkorelasi signifikan keberadaan TNGL sedangkan faktor jenis kelamin, umur, dan jumlah tanggungan keluarga berkorelasi tidak signifikan. Pada peran masyarakat faktor pendidikan berkorelasi signifikan, sedangkan faktor jenis kelamin, umur, pekerjaan dan jumlah tanggungan keluarga berkorelasi tidak signifikan. Pada kebijakan pemerintah seluruh faktor karakteristik berkorelasi tidak signifikan terhadap keberadaan TNGL.
\end{abstract}

Kata kunci : Pengetahuan Masyarakat, Peran Masyarakat, Kebijakan Pemerintah dan TNGL Desa Ketambe

\begin{abstract}
The existence of communities around TNGL is an inseparable part of the management of the National Park ecosystem, often faced with a dilemma between the interests of biodiversity conservation and the interests and needs of the community for resources in TNGL. This study aims to determine the level of public knowledge, the role of society and government policies on the existence of GLNP and to see the factors and levels of correlation that have an impact on public knowledge, the role of society and government policies. The method used in this study is to use the Statistical Program From Social Science (SPSS) 22 and Microsoft Excel 2007. Data processing is carried out using the Spearman Rank Correlation Test formula to test the relationship between variables. Based on the Spearman Rank correlation test on public knowledge, the work and education factors have a significant correlation with GLNP, while the factors of gender, age, and number of family dependents are not significantly correlated. In the role of the community, the education factor has a significant correlation, while the factors of gender, age, occupation and number of family dependents have no significant correlation. In government policy, all characteristic factors have insignificant correlation to the existence of TNGL.
\end{abstract}

Keywords: Community Knowledge, Community Role, Government Policy and TNGL in Ketambe Village

\section{PENDAHULUAN}

Aceh Tenggara adalah salah satu Kabupaten di Provinsi Aceh yang luasan wilayah seluas 4.165,63 $\mathrm{km}^{2}$. Secara umum dari potensi pengembangan ekonomi, wilayah ini termasuk zona pertanian. Daerah Kabupaten Aceh Tenggara terletak diketinggian \pm 200 2000 mdpl (dari permukaan laut )yang merupakan daerah pegunungan dan perbukitan. 
Sebagian kawasannya merupakan daerah suaka alam Taman Nasional Gunung Leuser (BBTNGL,2010).

TNGL merupakan salah satu Kawasan Pelestarian Alam di Indonesia seluas 1.094.692 ha yang secara administrasi pemerintahan terletak di Provinsi Aceh dan Sumatera Utara. Provinsi Aceh yang terdelinasi TNGL meliputi Kota Subulussalam, Aceh Selatan, Aceh Singkil, Aceh Tengah, Aceh Tenggara, Gayo Lues, Bener Meriah, Aceh Tamiang, sedangkan Provinsi Sumatera Utara yang terdelinasi TNGL meliputi Kabupaten Dairi, Karo, dan Langkat. TNGLjuga sebagai salah satu sumber penyokong kehidupan untuk memenuhi kebutuhan kehidupan sehari-hari masyarakat pinggir hutan. Ketergantungan yang sangat tinggi terlihat dari pemanfaatan jasa hutan secara langsung misalnya pengambilan kayu bakar, jasa ekowisata, perolehan air bersih dan lain-lain.

Pentingnya melibatkan masyarakat terhadap keberadaan TNGL sudah didasari oleh semua pihak yang berkepentingan terhadap pelestarian TNGL. Kendati peruntukan hutan konservasi itu telah diatur sedemikian rupa, namun tidak menutup kemungkinan kegiatan manusia di luar tujuan dari yang ditetapkan itu, baik kegiatan illegal maupun legal (Nasution, 1999). Peruntukan kawasan menjadi hilang, seperti pemburuan hewan, perambahan, illegalloging, dan kegiatan pariwisata. Padahal sebagai kawasan konservasi, TNGL seharusnya dipelihara mengingat hutan selain merupakan aset bangsa Indonesia, juga menjadi bagian dari kepentingan dunia. Maka perlu dilakukan penelitian untuk bisa menjawab bagaimana tingkat pengetahuan masyarakat, peran masyarakat dan kebijakan pemerintah terhadap keberadaan TNGL.

\section{METODE PENELITIAN}

\section{Lokasi}

Lokasi penelitian dilakukan di Desa Ketambe, Kecamatan Ketambe, Kabupaten Aceh Tenggara.

\section{Alat dan Bahan}

Penelitian ini menggunakan peralatan yaitu kamera sebagai sarana dokumentasi, alat tulis-menulis dan laptop untuk mengelola data. Sedangkan bahan yang digunakan adalah kuesioner sebagai pedoman wawancara untuk pengumpulan data dilapangan.

\section{Cara Kerja}

Dalam penelitian ini terdiri dari variabel terikat( Jenis kelamin, umur, pendidikan, pekerjaan, tanggungan keluarga) dan variabel bebas (pengetahuan masyarakat, peran masyarakat dan kebijakan pemerintah). Populasi dari penelitian ini adalah masyarakat yang berdomisili di Desa Ketambe dengan jumlah rumah tangga sebanyak 158 KK (BPS, Aceh Tenggara 2018). Penelitian ini dilakukan dengan pendekatan kuantitatif yang didukung dengan data kualitatif. Pengambilan data primer dilakukan melalui wawancara menggunakan kuisioner berdasarkan pilihan jawaban yang sudah disediakan. Analisis data yang dilakukan adalah analisis data kuantitatif dengan didukung data kualitatif dan kemudian dianalisis secara deskriptif. Untuk mengetahui hubungan keterkaitan antara variabel yang satu dengan yang lain, data kuantitatif dianalisis dengan menggunakan Statistical Program From Social Science (SPSS)22 dan Microsoft Excel 2007. Pengolahan data dilakukan menggunakan rumus Uji Korelasi Spearman Rank untuk menguji hubungan antar variabel yang berskala ordinal (non parametrik). 


\section{Parameter dan Analisis Data}

Parameter penelitian adalah jenis kelamin, umur, pendidikan, pekerjaan, tanggungan keluarga, pengetahuan, peran masyarakat dan kebijakan pemerintah. Analisis data dilakukan dengan menggunakan Statistical Program From Social Science (SPSS) 22, Microsoft Excel 2007 dan Uji KorelasiSpearman Rank.

\section{HASIL DAN PEMBAHASAN}

\section{Faktor-Faktor yang Mempengaruhi Pengetahuan Masyarakat, Peran Masyarakat dan Kebijakan Pemerintah}

Pada saat penelitian dilapangan, jumlah sampel responden yang diambil adalah 61 orang. Jumlah tersebut dianggap dapat mewakili keseluruhan jumlah masyarakat lokal Desa Ketambe dengan total populasi sebanyak $158 \mathrm{KK}$. Terdapat berbagai faktor karakteristik responden pada penelitian ini terdiri dari jenis kelamin, umur, pendidikan, pekerjaan dan jumlah tanggungan keluarga. Untuk mengetahui hubungan faktor-faktor tersebut maka dilakukan analisis Rank Spearman sehingga dapat diperoleh hasil.

Tabel 1. Hasil analisis korelasi rank spearman

\begin{tabular}{|c|c|c|}
\hline $\begin{array}{l}\text { Faktor } \\
\text { mempengaruhi } \\
\text { pengetahuan }\end{array}$ & Koefisien korelasi & Sig \\
\hline Jenis Kelamin & 0.003 & 0.800 \\
\hline Umur & -0.250 & 0.052 \\
\hline Pendidikan & $0.425 * *$ & 0.001 \\
\hline Pekerjaan & $0.259 *$ & 0.005 \\
\hline Tanggungan Keluarga & -0.231 & 0.073 \\
\hline
\end{tabular}

\begin{tabular}{lll}
\hline $\begin{array}{l}\text { Faktor } \\
\text { mempengaruhi peran }\end{array}$ & Koefisien korelasi & Sig \\
\hline Jenis Kelamin & -0.143 & 0.270 \\
Umur & -0.079 & 0.543 \\
Pendidikan & $0.333^{* *}$ & 0.001 \\
Pekerjaan & 0.237 & 0.066 \\
Tanggungan Keluarga & -0.042 & 0.747 \\
\hline
\end{tabular}

\begin{tabular}{|c|c|c|}
\hline $\begin{array}{l}\text { Faktor } \\
\text { mempengaruhi } \\
\text { kebijakan }\end{array}$ & Koefisien korelasi & Sig \\
\hline Jenis Kelamin & -0.047 & 0.718 \\
\hline Umur & 0.210 & 0.105 \\
\hline Pendidikan & 0.234 & 0.070 \\
\hline Pekerjaan & 0.036 & 0.784 \\
\hline Tanggungan Keluarga & 0.102 & 0.432 \\
\hline
\end{tabular}

Untuk pengujian signifikan dalam SPSS digunakan kriteria sebagai berikut: jika korelasi yang memiliki tanda $(*)$ artinya korelasi signifikan pada taraf $(0,05)$ sedangkan 
tanda $(* *)$ menunjukkan signifikan koreasi pada taraf $(0,01)$. Tabel diatas memperlihatkan bahwa fakor pekerjaan dan pendidikan berkorelasi signifikan terhadap pengetahuan dan faktor pendidikan juga berkoreasi signifikan terhadap peran masyarakat, sedangkan untuk kebijakan pemerintah seluruh faktor tidak berkorelasi signifikan.

\section{Analisis Korelasi Rank Spearman}

Tabel 2. Pengetahuan Responden

\begin{tabular}{cccc}
\hline No & Pengetahuan & Jumlah & Persentase \\
\hline 1 & Sangat Tinggi & 34 & 55.7 \\
2 & Tinggi & 16 & 26,2 \\
3 & Rendah & 9 & 14,8 \\
4 & Sangat Rendah & 2 & 3,3 \\
\hline & Jumlah & 61 & 100 \\
\hline
\end{tabular}

Berdasarkan hasil uji korelasi Rank Spearman menunjukkan bahwa variabel pendidikan dan pekerjaan seseorang berpengaruh nyata terhadap pengetahuan masyarakat. Hal ini dapat dilihat dari kekuatan hubungan pendidikan seseorang sebesar $0,425^{*}$ dengan nilai signifikan (2-tailed) adalah 0,001 dan kekuatan hubungan pekerjaan seseorang sebesar $0,259 *$ dengan nilai signifian (2-tailed) 0,005 . Artinya koefisien yang positif menunjukkan bahwa hubungan pendidikan dan pekerjaan dengan pengetahuan masyarakat memiliki hubungan yang searah. Tingkat pendidikan masyarakat di Desa Ketambe masih dikategorikan sangat rendah sesuai data profil Desa Ketambe 2019 bahwa mayoritas penduduk di Desa Ketambe adalah tamatan SD, hal ini juga menunjukkan bahwa tingkat pendidikan yang rendah bukan berarti tidak memiliki pengetahuan yang tinggi.

Tabel 3. Peran Masyarakat

\begin{tabular}{cccc}
\hline No & Pengetahuan & Jumlah & Persentase \\
\hline 1 & Sangat Tinggi & 0 & 0.0 \\
2 & Tinggi & 3 & 4.9 \\
3 & Rendah & 13 & 21.3 \\
4 & SangatRendah & 45 & 73.8 \\
\hline & Jumlah & 61 & 100 \\
\hline
\end{tabular}

Rendahnya tingkat keterlibatan masyarakat yang berperan terhadap keberadaan TNGL ini disebabkan karena dari segi pegembangan ekonomi di Desa ketambe termasuk kedalam zona pertanian dan masyarakat di Desa Ketambe lebih banyak menggantungkan hidupnya dengan cara bertani. Hal ini berbeda dengan penelitian Yulian Sadono (2013). Dalam Penelitiannya tentang peran serta masyarakat dalam pengelolaan Taman Nasional Gunung Merbabu di Desa Jeruk Kecamatan Selo, Kabupaten Boyolali, menyebutkan bahwa rendahnya tingkat pekerjaan masyarakat akan mendorong masyarakat untuk beraktifitas memanfaatkan hasil hutan sebagai sumber mata pencarian. 
Tabel 4. Kebijakan Pemerintah

\begin{tabular}{cccc}
\hline No & Pengetahuan & Jumlah & Persentase \\
\hline 1 & Sangat Tinggi & 1 & 1.6 \\
2 & Tinggi & 28 & 45.9 \\
3 & Rendah & 30 & 49.2 \\
4 & SangatRendah & 2 & 3.3 \\
\hline & Jumlah & 61 & 100 \\
\hline
\end{tabular}

Hasil uji korelasi Rank Spearman menunjukkan bahwa seluruh variabel tidak berpengaruh nyata terhadap kebijakan pemerintah. Hal ini dapat dilihat dari kekuatan hubungan umur sebesar 0,210 dengan nilai signifikan 0,105 kemudian nilai pendidikan sebesar 0,234 dengan nilai sinifikan 0,070 hubungan pekerjaan sebesar 0,036 dengan nilai signifikan 0,078 dan tanggungan keluarga sebesar 0,102 dengan nilai signifikan 0,432 artinya hubungan antara seluruh karakteristik responden dengan kebijakan pemerintah tidak signifikan. Hal ini disebabkan terdapat perbedaan cara pandang antara pemerintah dengan masyarakat sekitar terhadap keberadaan TNGL. Pemerintah memandang bahwa alam yang unik, khas, dan utuh harus dilindungi, sehingga penduduk sekitar merupakan ancaman sedang masyarakat memandang bahwa hutan merupakan hasil konstruksi sosial antara masyarakat dan ekosistem sekitarnya.

\section{KESIMPULAN}

1. Secara keseluruhan masyarakat di Desa Ketambe memiliki tingkat pengetahuan yang sangat tinggi terhadap keberadaan TNGL, sedangkan tingkat peran masyarakat memiliki tingkat peran sangat rendah, dan untuk tingkat kebijakan termasuk dalam kategori rendah.

2. Faktor yang berhubungan dengan pengetahuan masyarakat, peran masyarakat dan kebijakan pemerintah terhadap keberadan TNGL, yaitu faktor jenis kelamin, umur, pendidikan, pekerjaan dan tanggungan keluarga.

3. Berdasarkan uji korelasi Rank Spearman pada pengetahuan masyarakat, yakni faktor pekerjaan dan pendidikan berkorelasi signifikan keberadaan TNGL sedangkan faktor jenis kelamin, umur, dan jumlah tanggungan keluarga berkorelasi tidak signifikan.

4. Berdasarkan uji korelasi Rank Spearman pada peran masyarakat faktor pendidikan berkorelasi signifikan terhadap keberadaan TNGL sedangkan faktor jenis kelamin, umur, pekerjaan dan jumlah tanggungan keluarga berkorelasi tidak signifikan.

5. Berdasarkan uji korelasi Rank Spearman pada kebijakan pemerintah seluruh faktor karakteristik berkorelasi tidak signifikan terhadapkeberadaan TNGL.

\section{DAFTAR PUSTAKA}

Badan Pusat Statistik. 2018. Aceh Tenggara.Data Jumlah Masyarakat yang berdomisili di Desa Ketambe.

Balai Besar Taman Nasional GunungLeuser (BBTNGL). 2010. Rencanapengelolaan TNGL 2010-2029. BBTNGL, Medan.

Nasution, Muslimin, 1999. Hutan dan Persoalan Tanah Ulayat, dalam http://hppm.trip.co $\mathrm{m} /$ wacana2. html. (Diambil tanggal 21/05/2019).

Yulian Sadono. 2013. Peran Serta Masyarakat dalam Pengelolaan Taman Nasional Gunung 
Merbabudi Desa Jeruk Kecamatan Selo, Kabupaten Boyolali. 